\title{
Study on Effective Ways to Improve the Core Competitiveness of Innovative Smes
}

\author{
$\mathrm{Ai}-\min \mathrm{Cai}^{1, *}$ \\ ${ }^{1}$ Shandong Institute of Commerce and Technology, Jinan, Shandong, 250103, China \\ *Corresponding author. Email: caiaimin2000@163.com
}

\begin{abstract}
The core competitiveness of enterprises is an important factor to maintain the long-term stable development of enterprises, which can enable enterprises to occupy a stable position in the fierce market competition. By analyzing the survival environment faced by small and medium-sized enterprises, this paper studies the effective ways to improve the core competitiveness of innovative small and medium-sized enterprises, so as to provide valuable reference for the rapid and healthy development of small and medium-sized enterprises in shandong province and even the whole country.
\end{abstract}

Keywords: Middle and small-sized enterprises, Core competitiveness, Ecological effective path

\section{INTRODUCTION}

Since the reform and opening up, China's overall economy has witnessed rapid growth, especially small and mediumsized enterprises have made great progress. Small and medium-sized enterprises have become an important part of China's national economy, and become one of the main forces to promote the rapid development of China's economy. Promoting the development of small and medium-sized enterprises is an important strategy to promote the adjustment of national economic structure, and also an important link to achieve the strategic goal of innovation and entrepreneurship. However, with the indepth development of economic globalization, China's small and medium-sized enterprises face more and more competitive pressure, the competition environment is also more and more complex, many small and medium-sized enterprises lack of core competitiveness, life cycle is often very short. According to the survey, the average five-year mortality rate of smes in China exceeds $90 \%$, and the average life expectancy of smes is less than 3 years.

By analyzing the survival environment faced by small and medium-sized enterprises, this paper studies the effective ways to improve the core competitiveness of innovative small and medium-sized enterprises, so as to provide valuable reference for the rapid and healthy development of small and medium-sized enterprises in shandong province and even the whole country.

\section{ANALYSIS OF SURVIVAL ENVIRONMENT FACED BY SMES}

\subsubsection{The domestic environment}

The law of the People's Republic of China on the promotion of small and medium-sized enterprises is a law enacted to improve the business environment of small and medium-sized enterprises, promote their healthy development, expand urban and rural employment, and give play to the important role of small and medium-sized enterprises in the national economy and social development.

Take shandong province, which has the third largest economic value in China, as an example. In the past two decades, shandong province has continuously introduced policies to promote the healthy development of small and medium-sized enterprises, encouraging their rapid development. Shandong province people's government has issued "about to encourage the development of science and technology innovation of small and medium-sized enterprises of certain rules relating to the notice," to encourage the development of science and technology innovation of small and medium-sized enterprises in shandong province several money carries out detailed rules ", the small and medium-sized enterprises in shandong province to promote ordinance, "the shandong province science and technology innovation of small and mediumsized enterprise development the special support fund management interim measures" and a series of policies, the implementation of these policies, founded in small and medium-sized enterprises, innovation and development, improve the development of small and medium-sized enterprises environment, maintain the lawful rights and interests of small and medium-sized enterprises and promote the healthy development of small and mediumsized enterprises (smes) play a pivotal role.

\subsection{Policy Environment Analysis}




\subsubsection{The international environment}

Since US President Donald trump took office, the us has repeatedly increased tariffs on Chinese goods and banned Chinese high-tech companies from investing in the us.

"Area" strategy in our country, is the "silk road economic belt" and "Marine silk road" in the 21st century, relying on China and relevant countries existing multilateral mechanisms, with the help of the existing and effective regional cooperation platform, and actively develop along with the country's economic partnership, to create mutual political trust, economic integration, culture include the interests of the community, fate community and community responsibility. International cooperation on the "One Belt And One Road" will promote the alignment and coupling of development strategies of countries along the belt and road, promote inter-country connectivity, tap the potential of markets in the region, promote investment and consumption, and create demand and employment. Jointly building the "One Belt And One Road" will promote economic policy coordination among countries along the belt and road, and promote regional cooperation at a greater scope, level and depth. At present, the Chinese economy and the world economy are highly interconnected, and Chinese enterprises are highly interconnected with foreign enterprises. Chinese enterprises will certainly be highly integrated into the world economic system.

\subsection{Competitive Environment Analysis}

\subsubsection{Domestic competition is getting fiercer}

"Mass entrepreneurship and innovation" comes from premier li keqiang's speech at the summer davos forum in September 2014. Li keqiang proposed to launch a new wave of "mass entrepreneurship" and "grassroots entrepreneurship" on 9.6 million square kilometers of land, so as to form a new trend of "mass innovation" and "innovation for all". On September 18, 2018, the state council issued the opinions on promoting high-quality development of innovation and entrepreneurship and creating an upgraded version of "mass entrepreneurship and innovation", which has set off an unprecedented wave of entrepreneurship across the country. While streamlining administration and delegating power and creating a relaxed business environment, competition among enterprises has become increasingly fierce.

Shandong and zhejiang provinces, for example, have a bigger economy than zhejiang but less economic dynamism. In shandong province, traditional industries account for $70 \%$, and state-owned enterprises are the main force. Shandong province's economic characteristics are large but not strong, prominent structural contradictions, the lack of enterprise vitality. Zhejiang is a big province of private enterprises, all walks of life has a sound industrial chain, enterprise competitiveness is strong, full of vitality, development so far, it can be said that zhejiang businessmen in the country and even the world is a "magical existence".

With the proposal of China's innovation and entrepreneurship strategy, more and more people will be involved in the entrepreneurship boom, and the competition between enterprises will be more fierce, and the competition will be more brutal. Enterprises lacking competitiveness can only face elimination.

\subsubsection{International competition is getting tougher}

The world today is undergoing complex and profound changes. The deep impact of the international financial crisis is emerging, the world economy is diverging, and the pattern of international investment and trade and multilateral investment and trade rules are undergoing profound adjustments.

Nowadays, economic globalization and regional integration have become an irreversible trend of internationalization, which is bound to make market competition more intense. The international environment facing enterprises is constantly changing and technological means are constantly improving. Although smes are facing challenges on their development path, there are also opportunities. Co-construction of "One Belt And One Road" has brought new opportunities and challenges to China's small and medium-sized enterprises. In order to survive in the increasingly brutal competition and stand firm, many small and medium-sized enterprises in China must establish their own core competitiveness and constantly improve themselves in practice.

\section{AN EFFECTIVE WAY TO IMPROVE THE CORE COMPETITIVENESS OF SMES}

\subsection{An Effective Way To Improve The Core Competitiveness of Smes}

Economists prahalad and hamer first put forward the core competitiveness in harvard business review in 1990. They believed that "in the short run, the quality and performance of a company's products determine its competitiveness, but in the long run, it is decisive to build and enhance the company's core competitiveness". The concept of core competitiveness has been widely recognized by the 
academia and the business community, and has attracted the attention of entrepreneurs all over the world. But what is core competence? Different scholars have different views and definitions: prahalad and harmer are the core products and technologies of enterprises, namely the core competitiveness; Jay barney believes that the core resources and core capabilities of enterprises are the core competitiveness; Barton believes that knowledge and learning are core competencies. Rafa and zorro believe that the core competitiveness of enterprises is formed through long-term accumulation, which is permeated into the corporate culture and develops with the development of corporate culture[1].

In general, the core competitiveness of an enterprise is a factor that can maintain the long-term stable development of the enterprise and obtain the competitive advantage. To be specific, core competitiveness refers to the irreplaceable ability of an enterprise to keep adapting to environmental changes and keep it higher than its competitors. Meanwhile, this ability should be long-term and irreplaceable. As an independent economic entity, enterprise competitiveness is formed by the allocation and creation of enterprise resources in competitive market and the organic combination of its resources. It is able to compare with other enterprises in the same industry in terms of market ownership, value creation and development maintenance. Enterprise competitiveness is a relatively abstract comprehensive concept with multi-level meanings, which contains two meanings: first, the core competitiveness is owned by enterprises, and it is difficult or impossible for competitors to replicate in a short period of time. Second, core competitiveness is the ability to bring excess profits to enterprises. It can be said that the core competitiveness is the most important and critical capability among all the capabilities of an enterprise[2]. The strength of the core competitiveness determines the position and destiny of an enterprise in the market competition.

In many small and medium-sized enterprises, the core competence has not been the leadership attaches great importance to, companies often only pay attention to, head of the production and market, the value is the enterprise management and product marketing, in the intense domestic competition and cruel face international competition, small and medium-sized enterprises want to survive and development, also must foster and strengthen the core competitiveness of enterprises.

\subsection{The Effective Path to Improve The Core Competitiveness}

\author{
3.2.1 Enterprise development strategy \\ innovation is the premise of promoting core \\ competitiveness
}

Small and medium-sized enterprises should keep up with regional development heights and update their industries in a timely manner. Instead of sticking to traditional industries and seeking no changes, they should adjust their development strategies, deploy future-oriented innovation initiatives in advance, and seize the commanding heights of development actively. In the face of the global economy, since the outbreak of the financial crisis, the world economy has entered a long period of deep adjustment. Major developed countries and emerging economies have also adjusted their development strategies. In early 2018, the shandong provincial government issued by the major project in shandong province on the kinetic energy conversion between the old and the new proposed new kinetic energy conversion implementation plan notice explicitly put forward structural reforms to the supply side as the main line, with new technologies, new industries and new forms, new model as the core, with knowledge, technology, information, data, and so on new production elements to support the industry system. In the face of the old and new kinetic energy conversion strategy, small and medium-sized enterprises is faced with new challenges and opportunities in east China's shandong province, the new policy implementation, will push the change of new enterprises, small and medium-sized enterprises in the change either die, or growth, so to change development strategy is to improve the core competitiveness of the important premise, it determines the enterprise's development direction, fate walk home.

\subsubsection{Cultural innovation is the basis for improving core competitiveness}

Corporate culture can influence other factors of an enterprise's core competitiveness, and the innovation of corporate culture can promote the innovation of enterprise management and production technology. Corporate culture is the soul of an enterprise. It can form the overt symbols or rituals of the enterprise and form the implicit values or spiritual qualities of the enterprise. Cultural innovation is the foundation of enterprise innovation and the foundation of enhancing enterprise core competitiveness. Only by shaping and supporting the enterprise culture of innovation can smes attract innovative talents. China has a history and culture of more than 5,000 years, and shandong province is a major cultural province and the birthplace of Confucian culture. 
Corporate culture can promote enterprises to leave a good impression in the market, so that consumers recognize enterprises, trust enterprises, thus increasing the stable customer rate. Innovative small and medium-sized enterprises should be the organic combination of tradition and innovation, innovative culture in the inheritance, build respect individuality, respect for talent, innovation, enterprising, accept risk, tolerate failure of open, diversified enterprise culture atmosphere, from the aspects of enterprise concept, rewards and punishment system to encourage employees to share resources, wisdom, innovation, to reach the company's values, rules and regulations, code of conduct, symbolic ceremony, such as the unity of content and form, promote cultural innovation ability, so as to promote the core competitiveness of innovative small and medium-sized enterprises (smes).

\subsubsection{Technological innovation is the key to improving core competitiveness}

Technological innovation ability is the source of the core competitiveness of innovative smes and the source of the development of innovative smes. A new round of technological revolution and industrial revolution speed, the gathering burst, especially information technology, biological technology, manufacturing technology, new materials, new energy technology widely penetrated into various fields, such as technology innovation is a new engine to the growth of enterprise competition ability, enterprises improve the quality of our products or services, plays a key role in the technological innovation capability of firms.

\subsubsection{Management innovation is the guarantee of improving core competitiveness}

The enterprise's management mode and management resources have a great influence on the enterprise's core competitiveness. If an enterprise has technology and talents, but no scientific and reasonable management mode or management resources, then there will be technological wastage, brain drain consequences[3]. Among the basic functions of management, the innovation function permeates every link of planning, organization, command, coordination and control. Management innovation ability covers enterprise system innovation, organizational structure innovation, management technology and method innovation, including innovation management profit rate, leadership innovation consciousness, internal and external organizational coordination ability, institutional innovation and organizational change ability, management innovation method application and other factors[4]. Excellent management innovation ability is a strong guarantee to enhance the core competitiveness of smes.

\subsubsection{Integration into the global economy is a window to enhance core competitiveness}

The pattern of global integration is taking shape, and the co-construction of "One Belt And One Road" has accelerated the economic cooperation between China and other countries[5]. Small and medium-sized enterprises (smes) are unable to compete with large domestic enterprises due to their small scale. Therefore, going global and integrating into the international economy is an effective way to promote the continuous growth of enterprises. Enterprise growth mainly includes: customer growth rate, main business revenue growth rate, profit growth rate, total asset growth rate four aspects. Compared with large and medium-sized enterprises, it is difficult for innovative smes to have cost advantages. Therefore, smes should implement differentiation strategy to drive differentiation through innovation. By integrating into the global development window, it is easier to find distinctive products or services, go international, build the brand and characteristics of international products, and expand the customer group and increase the growth rate of customers.

\section{CONCLUSION}

In a word, with the increasing complexity of the market environment, the core competitiveness of smes is related to the development of the lifeline of enterprises. It plays a positive role in the development of small and mediumsized enterprises by comprehensively analyzing the environment of enterprises, studying the effective path of improving the core competitiveness of enterprises, and forming innovative enterprises. By analyzing the living environment faced by small and medium-sized enterprises in China, this paper studies the path to improve the core competitiveness of innovative small and medium-sized enterprises, explores and gives an effective plan, which provides valuable reference for the rapid and healthy development of small and medium-sized enterprises in Shandong province and even the whole country.

\section{ACKNOWLEDGMENT}

This work was supported by the first construction unit of the high-level vocational schools and specialty construction plan project with Chinese characteristics (no. 14 of faculty letter (2019)) -- A project construction school shandong vocational and technical college of commerce; Shandong province management research project "shandong province innovative smes core competitiveness research" (project no. JZ201916). 


\section{REFERENCES}

[1] $\mathrm{Yu}$ die. [Research on the development countermeasures of smes based on their core competitiveness]. China management informatization,2019(22):79-80. (in Chinese)

[2] Li zhiming. [Construction of core competitiveness of smes in China]. Coal economics research, 2009 (4) : 26-27. (in Chinese)

[3] Liu cuiying. [Problems and countermeasures in the construction of core competitiveness of small and medium-sized enterprises]. Journal of science and technology economics, 2008, 26 (34) :182-183. (in Chinese )

[4] Wang haiyun. [On the core competitiveness of smes]. Modern industrial economy and informatization,2019(5):11-12,25. (in Chinese)

[5] Cheng kaiyu. [Research on the core competitiveness of smes in the context of cross-border e-commerce] Guide to science and technology economy, 2019,27 (19) :238 (in Chinese) 